\title{
NEW OCCURRENCE OF RARE PROTECTED MOSS SPECIES BUXBAUMIA VIRIDIS (BRYOPSIDA, BUXBAUMIACEAE) IN THE BIAŁOWIEŻA FOREST
}

\author{
Anna Szczepaniuk, Jan KucharzyK
}

\begin{abstract}
A. Szczepaniuk, J. Kucharzyk, Department of Plant Ecology and Environmental Conservation, Institute of Botany, Faculty of Biology, Biological and Chemical Research Centre, University of Warsaw, Żwirki i Wigury 101, 02-096 Warsaw, Poland; Centrum Ochrony Mokradeł, ul. Cieszkowskiego 1/3 lok. 31, 01-636 Warsaw, Poland, e-mail: ania.szczepaniuk@gmail.com, j.kucharzyk@bagna.pl
\end{abstract}

(Received: May 25, 2016. Accepted: June 8, 2016)

\begin{abstract}
AвSTRAct. The Green Shield-moss Buxbaumia viridis (Bryopsida, Buxbaumiaceae) is an endangered, legally protected bryophyte considered as an ancient forest species both in Poland and elsewhere in Europe. This paper presents new localities for NE Poland, specifically in the Białowieża Forest. As an epixylous species, it is threatened by logging and intensive forest management. It is of utmost importance to protect this species' habitat, particularly at the present time when increased logging is proposed.
\end{abstract}

KEY WORDs: Buxbaumia viridis, Białowieża Forest, rare species, primeval forest relics

\section{INTRODUCTION}

Buxbaumia viridis (Moug. ex Lam. \& DC.) Brid. ex Moug. \& Nestl. is an endangered (category E) moss species (ŻARNOWIEC et al. 2004), protected by law in Poland (RozPorządzenie... 2014), by the Bern Convention (Konwencja... 1979) and Habitat Directive 92/43/EEC (DYREKTYWA... 1992) and also considered to be endangered (category E) in Europe (SCHUMACKER \& MARTINY 1995).

Buxbaumia viridis is characterised by minute gametophytes $(1 \mathrm{~mm})$ resembling protonema, without typical leaves, which makes this species difficult to detect during the haploid phase. The shoots can be observed only when the sporophytes develop, from autumn until late spring. The seta $(5-7 \mathrm{~mm})$ bears a prominent capsule $(5-8 \mathrm{~mm})$, firstly green, later (when mature) it becomes brown (STEBel 2004, Vončina 2012). Buxbaumia viridis is defined as an epixylous species, growing on logs of dead trees bereft of bark in advanced state of decay, mainly on fir and spruce, rarely on beech (Stebel 2004, Hajek 2008, 2010, KozIK \& VončInA 2012, VončInA 2012, Vončina \& Chachuta 2012, KuCharzyK et al. 2016 unpbl.). The species is also rarely observed on soil humus and on layers of soil covering stones (HAJEK 2010, KuCHARZYK 2016 unpbl.).

In Poland, Buxbaumia viridis is documented mainly from the south-eastern part of the country, from different forest communities, e.g.: Dentario glandulosae-Fagetum abietetosum, Carici albae-Fagetum abietetosum, Carici albae-Fagetum typicum, Abieteti-Piceetum montanum and Tilio-Carpinetum (SzMAJDA et al. 1991, Phillippe \& Ochyra 2004, Stebel 2004, CykowsKa 2008, Vončina 2008, 2012, Chachuta \& VončInA 2010, Cykowska \& Vončina 2011, Vončina et al. 2011, KozIK \& VonČINA 2012, ZARZECKI 2012, TopolSKA \& KuCharzYK 2014-2016 unpbl., Fudali et al. 2015, KuChARZYK \& TOPOLSKa 2015). It was also reported in the northern part of Poland - in the vicinity of Elbląg and Gdańsk, in Luzulo pilosale-Fagetum and Stellario-Carpinetum communities (НАјEK 2008, 2010, 2012). South-western localities are known from Sudetes (Szmajda et al. 1991, SMoczyK \& WierzcholsKa 2008, CYKowsKa \& Vončina 2011).

Currently, the nearest localities to the Podlasie region are known from Roztocze Upland - Świerszcz river valley (FudALI et al. 2015). The species has not been recorded so far neither from the Belarusian part of Białowieża Forest nor the country of Belarus (RYKOVSKY \& MASLOVSKY 2004). 


\section{MATERIAL AND METHODS}

All the information given on current localities derives from our own studies, surveyed during the spring of 2016. The localities listed below are presented according to the Atmos grid square system (OchYra \& SzMAJDA 1981). The bryological nomenclature follows OCHYRA et al. (2003) and SzWEYKowski (2006), categories of threat are given after ŻARNOWIEC et al. (2004), geographical names follow KONDRACKI (2001).

\section{RESULTS}

A detailed description of Buxbaumia viridis occurrence on the newly discovered localities in Białowieża Forest is given below.

ATMOS Cg-55: NE Poland, Podlasie Lowland, Bielska Plain, NE part of the Białowieża forest division (department $250 \mathrm{D}$ ), $52.765^{\circ} \mathrm{N}, 23.757^{\circ} \mathrm{E}$.

A total of 66 sporogones were observed on the extent of ca. $300 \mathrm{~cm}$ of the rotten log of Quercus robur, without a bark, in a Tilio-Carpinetum community. The accompanying species were: Herzogiella seligeri, Eurhynchium angustirete, Orthodicranum montanum, Lophocolea heterophylla, Rhizomnium punctatum, Lepidozia reptans, Plagiothecium laetum, Dicranum scoparium, Hypnum cupressiforme, Nowellia curvifolia and Jamesoniella autumnalis, det. A. Szczepaniuk, 3.05.2016.

A total of 12 sporogones were observed on the extent of ca. $70 \mathrm{~cm}$ of the rotten log of Quercus robur, without a bark, in a Tilio-Carpinetum community. The accompanying species were: Hypnum cupressiforme, Herzogiella seligeri, Jamesoniella autumnalis and Lophocolea heterophylla, det. J. Kucharzyk, 3.05.2016.

\section{DISSCUSSION}

The records of Buxbaumia viridis we provided are first occurrences of the species in the Białowieża Forest. Previously unknown type of substrate inhabited by the spiecies in Poland - decaying wood of Quercus robur - have been revealed. Typically this moss is confined to rotten wood of spruce and fir, often in stream valleys (SMOczyK \& WierzcholsKa 2008, VonČINA 2008,2012 , СhachuŁa \& VonČIna 2010, CyKowsKa \& VonČINA 2011, ZARZECKI 2012, TOPOLSKA \& KUCHARZYK 2014-2016 unpbl., KuCHARZYK \& TOPOLSKA 2015).

Buxbuamia viridis is considered to be an ancient forest species (CieślińsKi et al. 1996, STEBel \& ŻarNOWIEC 2014).

Our discovery confirms that the Białowieża Forest is an important refugium for an array of ancient forest species. Buxbaumia viridis is mainly known from isolated localities in extensive forest areas, where the forest management is not intensive (or is abandoned), largely from the national parks or nature reserves. The most significant threats for the species are: an increase of insolation, a decrease of moisture and forest logging. It seems to be a very important issue in light of the new logging plan for the Białowieża Forest, resulting in increased timber harvesting (ANEKs... 2016). The forests with newly discovered localities of $B$. viridis should be entirely excluded from logging (see STEBEL 2004).

\section{ACKNOWLEDGEMENTS}

We would like to thank Dr. Sylwia Wierzcholska (University of Warsaw, Geobotanical Station in Białowieża) for relevant comments on the manuscript and bryophytes identification, and to Dr. Richard Broughton (CEH, Natural Environmental Research Council, UK) for improving the English version of the paper.

\section{REFERENCES}

ANEKs do planu urządzenia lasu dla Nadleśnictwa Białowieża sporząqdzonego na lata 2012-2021 zatwierdzony Decyzją Ministra Środowiska. (2016). Znak DLP-I.611.16.2016 z dnia 25 marca 2016 r.

Chachuta P., Vončina G. (2010): The discovery of Buxbaumia viridis (Bryophyta, Buxbaumiaceae) in the Bieszczady National Park. Roczniki Bieszczadzkie 18: 419-423.

Cieśliński S., Czyżewska K., Faliński J.B., Klama H., Mutenko W., Żarnowiec J. (1996): Relikty lasu puszczańskiego. Zjawiska reliktowe. (Wyniki badań w Projekcie CRYPTO na stałej powierzchni BSG: V-100; BPN; oddz. 256). Phytocoenosis 8 (N. S.), Seminarium Geobotanicum 4: 47-64.

CүкошsкA B. (2008): New records of Buxbaumia viridis (Bryophyta, Buxbaumiaceae) in the Polish Carpathians. In: A. Stebel, R. Ochyra (eds). Bryophytes of the Polish Carpathians. Sorus, Poznań: 251-256.

Cykowska B., Vončina G. (2011): Recent occurrence of moss Buxbaumia viridis (Bryophyta, Buxbaumiaceae) in the Kłodzko region (Central and Eastern Sudetes, SW Poland). Casopis Slezského zemského muzea, Opava (A) 60: 85-89.

DyrekTYWA Rady 92/43/EWG z dnia 21 maja $1992 \mathrm{r}$. $\mathrm{w}$ sprawie ochrony siedlisk przyrodniczych oraz dzikiej fauny i flory. (1992). Dz.U. L 206, 22/07/1992 P. 0007-0050, zmieniona Dyrektywa 97/62/EWG z dnia 27 października $1997 \mathrm{r}$.

Fudali E., Zubel R., Stebel A., Rusińska A., Górski P., Vončina G., Rosadziński S., Cykowska-Marzencka B., Staniaszek-Kik M., Wierzcholska S., Wolski G.J., Wojterska M., Wilhelm M., Paciorek T., Piwowarski B. (2015): Contribution to the bryoflora of the Roztocze National Park (SE Poland) Bryophytes of the Świerszcz river valley. Steciana 19(1): 39-54. doi 10.12657/steciana. 019.006.

HAJeK B. (2008): Charakterystyka współczesnych stanowisk mchu Buxbaumia viridis na Wysoczyźnie 
Elbląskiej (Polska północna). Parki Narodowe i Rezerwaty Przyrody 27(4): 27-34.

HAJeK B. (2010): Rozmieszczenie, wymagania środowiskowe oraz fenologia rzadkiego mchu Buxbaumia viridis (Moug. ex Lam. \& DC.) Brid. ex Moug. \& Nestl. (Bryophyta, Buxbaumiaceae) w Trójmiejskim Parku Krajobrazowym. Acta Botanica Cassubica 7-9: 161-175.

HAJEK B. (2012): Nowe stanowisko rzadkiego mchu Buxbaumia viridis (Moug. ex Lam. \& DC.) Brid. ex Moug. \& Nestl. (Bryophyta, Buxbaumiaceae) na Pomorzu Gdańskim. Acta Botanica Cassubica 11: 207-211.

KaRCZMARZ K. (1965): Zapiski briologiczne z Lubelszczyzny. Bryological records from the Lublin Region (Eastern Poland). Fragmenta Floristica et Geobotanica 11(3): 409-419.

KondRACKI J. (2001): Geografia regionalna Polski. Wydawnictwo Naukowe PWN, Warszawa.

KonWENCjA o ochronie gatunków dzikiej flory i fauny europejskiej oraz ich siedlisk, sporządzona w Bernie dnia 19 września 1979 r. (1979). http://isap.sejm.gov.pl/DetailsServlet?id=WDU19960580263 (access: 10.05.2016).

KoziK J., Vončina G. (2012): Odkrycie bezlistu okrywowego Buxbaumia viridis (Bryopsida, Buxbaumiacae) w Beskidzie Niskim (Karpaty Zachodnie). Roczniki Bieszczadzkie 20: 378-383.

KucharzyK J., TOPOLsKa K. (2015): Inwentaryzacja przyrodnicza bezlistu okrywowego Buxbaumia viridis (Moug. ex Lam. \& DC.) Brid. ex Moug. \& Nestl. W obszarze Natura 2000 „Eysa Góra” PLH180018 (mscr.). Regionalna Dyrekcja Ochrony Środowiska w Rzeszowie, Warszawa - Myscowa: $1-22$.

OChYRA R., SzmajDA P. (1981): La cartographie bryologique en Pologne. In: J. Szweykowski (ed.). New perspectives in bryotaxonomy and bryogeography. Uniwersytet A. Mickiewicza, Poznań, Seria Biologia 20: 105-110.

Ochyra R., Żarnowiec J., BednareK-Ochyra H. (2003): Census catalogue of Polish Mosses. Biodiversity of Poland. Vol. 3. Institute of Botany, Polish Academy of Sciences, Kraków: 1-372.

Phillippe M., Ochyra R. (2004): Occurrence of the moss Buxbaumia viridis (Bryophyta, Buxbaumiaceae) in the Tatra National Park (Poland). In: A. Stebel, R. Ochyra (eds). Bryological studies in the Western Carpathians. Sorus, Poznań: 29-36.

RozPORZĄDZENIE Ministra Środowiska $z$ dnia 9 października 2014 r. w sprawie ochrony gatunkowej roślin.(2014). Dz.U. 2014, poz. 1409.

Ryкоvsky G.F., Maslovsky M.O. (2004): Flora of Belarus. Bryophytes. Vol. 1. Andreaeaopsida-Bryopsida. Technalohija, Minsk: 1-437.

Schumacker R., Martiny PH. (1995): Threatened bryophytes in Europe including Macronesia. In: Red data book of European bryophytes. Part 2: Threat- ened bryophytes in Europe including Macaronesia. European Committee for Conservation Bryophytes, Trondheim: 29-193.

Smoczyk M., Wierzcholska S. (2008): Wyniki badań botanicznych jako podstawa do rozszerzenia sieci obszarów Natura 2000 w zachodniej części Ziemi Kłodzkiej. In: M. Furmankiewicz, B. Mastalska-Cetera (eds). Problemy wdrażania sieci Natura 2000 na obszarze Sudetów. Muzeum Przyrodnicze w Jeleniej Górze, Jelenia Góra: 101117.

Stebel A. (2004): Buxbaumia viridis - bezlist okrywowy. In: B. Sudnik-Wójcikowska, H. Werblan-Jakubiec H. (eds). Poradniki ochrony siedlisk i gatunków Natura 2000 - podręcznik metodyczny. T. 9. Gatunki roślin. Ministerstwo Środowiska, Warszawa: 29-32.

Stebel A., Żarnowiec J. (2014): Gatunki puszczańskie we florze mchów Bieszczadzkiego Parku Narodowego (Karpaty Wschodnie) - The primeval forest species in the moss flora of the Bieszczady National Park (Eastern Carpathians). Roczniki Bieszczadzkie 22: 259-277.

Szmajda P., Bednarek-Ochyra H., Ochyra R. (1991): M. 639. Buxbaumia viridis (DC.) Moug. \& Nestl. In: R. Ochyra, P. Szmajda (eds). Atlas of the geographical distribution of spore plants in Poland. Series V. Mosses (Musci). Part 7. W. Szafer Institute of Botany, Polish Academy of Sciences, Adam Mickiewicz University, Kraków-Poznań: 47-52.

SzWEYKowsKi J. (2006): An annotated checklist of Polish liverworts and hornworts. - Krytyczna lista wątrobowców i glewików Polski. Biodiversity of Poland. Vol. 4. W. Szafer Institute of Botany, Polish Academy of Sciences, Kraków

Vončina G. (2008): The occurrence of Buxbaumia viridis (Bryophyta, Buxbaumiaceae) in the Pieniny National Park (Polish Western Carpathians). In: A. Stebel, R. Ochyra (eds). Bryophytes of the Polish Carpathians. Sorus, Poznań: 243-250.

Vončina G. (2012): Bezlist okrywowy Buxbaumia viridis (Moug. ex Lam. \& DC.) Brid. ex Moug. \& Nestl.). In: J. Perzanowska (ed.). Monitoring gatunków roślin. Przewodnik metodyczny. Cz. 2. GIOŚ, Warszawa: 40-52.

Vončina G., Chachuta P. (2012): Aktualne występowanie bezlistu okrywowego Buxbaumia viridis (Bryophyta, Buxbaumiaceae) w Pienińskim Parku Narodowym (Polska). Pieniny-Przyroda i Człowiek 12: 81-86.

Vončina G., Cyкowska B., Chachuta P. (2011): Rediscovery of Buxbaumia viridis (Bryophyta, Buxbaumiaceae) in the Tatra and Gorce in Polish Western Carpathians. In: A. Stebel, R. Ochyra (eds). Chorological studies on Polish Carpathian bryophytes. Sorus, Poznań: 171-176.

ZARzeCKI R. (2012): Nowe stanowiska Buxbaumia viridis (Buxbaumiaceae, Bryophyta) $\mathrm{w}$ południo- 
wo-wschodniej Polsce [New localities of Buxbaumia viridis (Buxbaumiaceae, Bryophyta) in the south-eastern Poland]. Fragmenta Floristica et Geobotanica Polonica 19 (2): 561-564.

Żarnowiec J., Stebel A., Ochyra R. (2004): Threatened moss species in the Polish Carpathians in the light of a new Red list of mosses in Poland.
In: A. Stebel, R. Ochyra (eds). Bryological studies in the Western Carpathians. Sorus, Poznań: 9-28.

For citation: SzCZEPANIUK A., KuCHARZYK J. (2016): New occurrence of rare protected moss species Buxbaumia viridis (Bryopsida, Buxbaumiaceae) in the Białowieża Forest. Steciana 20(2): 93-96. doi: 10.12657/steciana.020.011 